\title{
Cytogenetical Analyses in Three Astyanax scabripinnis Populations (Pisces, Characidae) from Minas Gerais State, Brazil
}

\author{
Sandra Helena Biavati ${ }^{1}$ and Edson Luis Maistro ${ }^{2, *}$ \\ ${ }^{1}$ Universidade de Lavras, Lavras, Minas Gerais, Brazil \\ ${ }^{2}$ Departamento de Fonoaudiologia, Faculdade de Filosofia e Ciências, \\ Universidade Estadual Paulista (UNESP), Marília, São Paulo, Brazil
}

Received August 6, 2007; accepted August 20, 2007

\begin{abstract}
Summary Cytogenetical data in 3 populations of characid fish assigned to the "complex" of Astyanax scabripinnis from São Francisco river basin and Grande river basin, Minas Gerais State, Brazil, are presented for the first time. The same diploid number, $2 n=50$, was detected in the 3 populations, which has conspicuous differences involving karyotype morphology: 8M, 20SM, 6ST and 16A (Cambeba stream), 6M, 28SM, 6ST and 10A (Machado headwater), 6M, 24SM, 8ST and 12A (Pedra Branca stream). Differences involving amount and/or locations of heterochromatin blocks, number and position of nucleolar organizer regions (NORs) and $\mathrm{CMA}_{3}$ positive signals were also observed. Some aspects related to the chromosome diversification of Astyanax scabripinnis are discussed.
\end{abstract}

Key words Astyanax scabripinnis, Characidae, Fish cytogenetics, NOR-banding, C-banding.

The genus Astyanax, whose representatives are popularly known as characins, are distributed from the South of United States to Northern Argentina (Eigenmann 1921). This Neotropical genus comprises about 74 species (Eigenmann 1921), several of them inhabiting hard waters. Yet, this number is not precise and, most likely, there are many species to be described (Melo 2001).

Astyanax scabripinnis present several interesting peculiarities for chromosomal evolutionary studies, i.e., a large number of subspecies described (Fowler 1948), shows geographic distribution restricted to hardwaters of small streams (Gomes and Azevedo 1960), phenotypic plasticity (Caramaschi 1986, Moreira-Filho and Bertollo 1991, Maistro et al. 1998, Mizoguchi and Martins-Santos 1998), and high karyotype diversity (Souza et al. 1995).

The purpose of this paper is to describe the diploid number, karyotype, constitutive heterochromatin pattern, NOR and $\mathrm{CMA}_{3}$ positive sites location of 3 Astyanax scabripinnis local populations collected in small tributaries of 2 different hydrographic basins on Minas Gerais State, Brazil.

\section{Material and methods}

A cytogenetic survey was performed on 3 different populations of Astyanax scabripinnis originated from Minas Gerais, Brazil, river hardwaters close to the large riverine basins of the São Francisco river (Cambeba stream, Arcos town (4 females)), and Grande river (Machado river, São João da Mata town (9 females, 2 males and 1 sex indetermined), and Pedra Branca stream, Alfenas town (12 females and 2 males)) (Fig. 1). Voucher specimens are deposited in the fish collection of the

*Corresponding author, e-mail: edson.maistro@marilia.unesp.br 


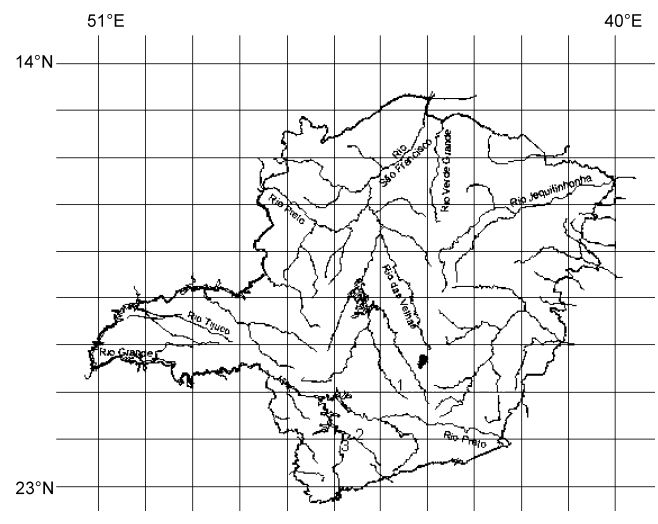

Fig. 1. Minas Gerais State (Brazil) hydrographic map showing Astyanax scabripinnis collect sites: 1) Cambeba stream, 2) Machado river hardwater, and 3) Pedra Branca stream.
Laboratory of Genetics, UNIFENAS, Alfenas, Minas Gerais, Brazil.

Chromosome preparation: Animals were injected with $0.025 \%$ colchicine $(1 \mathrm{ml} / 100 \mathrm{~g}$ body weight) $50 \mathrm{~min}$ before sacrifice. Anterior kidney was excised and minced in a $0.075 \mathrm{M}$ $\mathrm{KCl}$ solution, placed in a incubator at $37^{\circ} \mathrm{C}$ for $23 \mathrm{~min}$ and then centrifuged. The supernatant was discarded and the cell pellet was fixed twice in a methanol: acetic acid $(3: 1)$ solution, ressuspended in fresh fixative and dropped on heated slides (Bertollo et al. 1978, Foresti et al. 1993). Chromosome preparations were stained with a $5 \%$ Giemsa staining solution. Chromosome morphology was determined on the basis of arm ratios as proposed by Levan et al. (1964) and the chromosomes were classified as

metacentric (M), submetacentric (SM), subtelocentric (ST) and acrocentric (A), and were paired by decreasing size order. The fundamental number (FN) was determined considering M/SM/ST chromosomes to have two arms and A chromosomes to have one arm. C-banding was performed by the method of Sumner (1972), silver-staining of the nucleolus organizer regions was performed by the technique of Howell and Black (1980), and Chromomycin $\mathrm{A}_{3}$ staining was performed by the method of Schweizer (1980).

\section{Results and discussion}

All local populations analyzed in the present study showed the same diploid number of $2 n=50$ chromosomes, with the following chromosome constitutions: to Cambeba stream a total of 48 metaphases were analysed and the standard karyotype consists of $8 \mathrm{M}+20 \mathrm{SM}+6 \mathrm{ST}+16 \mathrm{~A}$; to Machado hardwater 238 metaphasic cells were analysed and the standard karyotype consists of $6 \mathrm{M}+28 \mathrm{SM}+6 \mathrm{ST}+10 \mathrm{~A}$; and to Pedra Branca stream a total of 326 cells were analysed and the standard karyotype consists of $6 \mathrm{M}+24 \mathrm{SM}+8 \mathrm{ST}+12 \mathrm{~A}$ (Fig. 2a, b, c, respectively). No chromosomal differences were detected between sexes. Including the present investigation, cytogenetic studies have been carried out thus far on more than fourth local populations of $A$. scabripinnis from different Brazilian regions. In this studies, 3 diploid numbers have been already detected: $2 n=46$, $2 n=48$ and $2 n=50$ (Souza et al. 1995, Mizoguchi and Martins-Santos 1998, Maistro et al. 1998, 2001). In this species, such karyotypic differences seem not to be related to the geographic distribution of the populations since fishes with different diploid numbers can be found nearby each other or in the same stream (Maistro et al. 2000).

Populations examined in the present study showed different numbers of metacentric, submetacentric, subtelocentric and acrocentric chromosomes (Fig. 2a, b, c). The combinations of karyotypes found were inside the limits previously described for populations of $A$. scabripinnis, with $2 n=50$ chromosomes ranging from 36M-SM+14ST-A $(\mathrm{FN}=86)$ to $14 \mathrm{M}-\mathrm{SM}+36 \mathrm{ST}-\mathrm{A}(\mathrm{FN}=64)$ (Souza et al. 1995).

The pattern of heterochromatin distribution was characteristic for each population under study, with differences in the amount and/or distribution pattern being observed in each of them (Fig. $3 \mathrm{a}, \mathrm{b}, \mathrm{c})$. These results are in accordance with the purpose that the C-banding pattern distribution has been the best discriminating feature for the local populations of A. scabripinnis (Moreira-Filho and Bertollo 1991, Mizoguchi and Martins-Santos 1998, Maistro et al. 1998, Mantovani et al. 


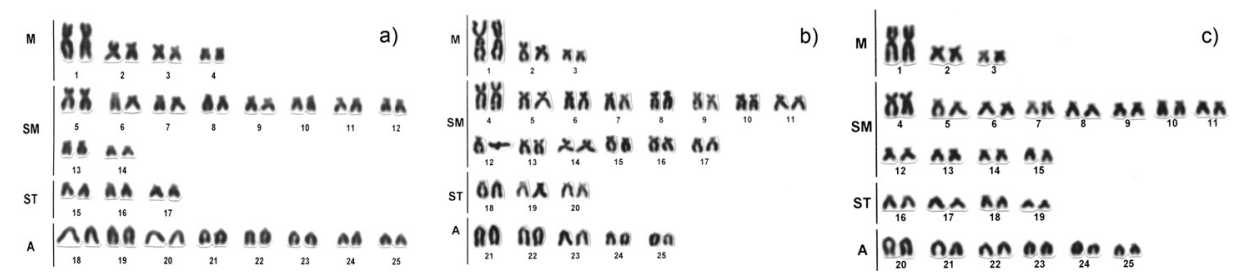

Fig. 2. Karyotypes of Astyanax scabripinnis after Giemsa staining: a) sample from Cambeba stream, b) sample from Machado river hardwater, and c) sample from Pedra Branca stream.

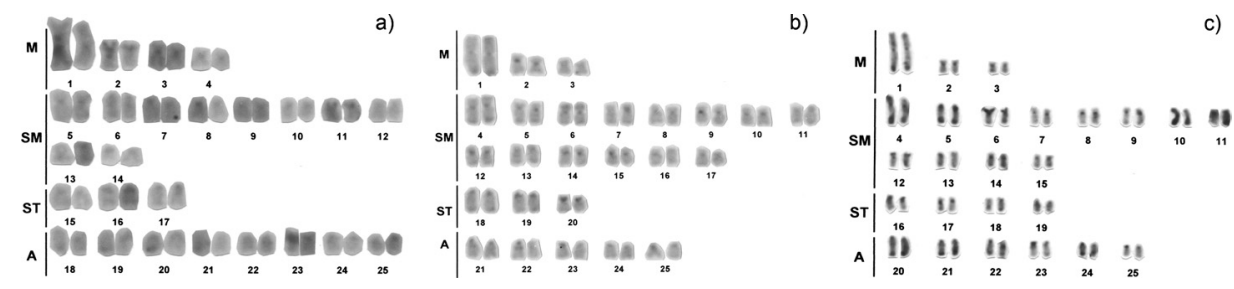

Fig. 3. Karyotypes of Astyanax scabripinnis after C-banding: a) sample from Cambeba stream, b) sample from Machado river hardwater, and c) sample from Pedra Branca stream.
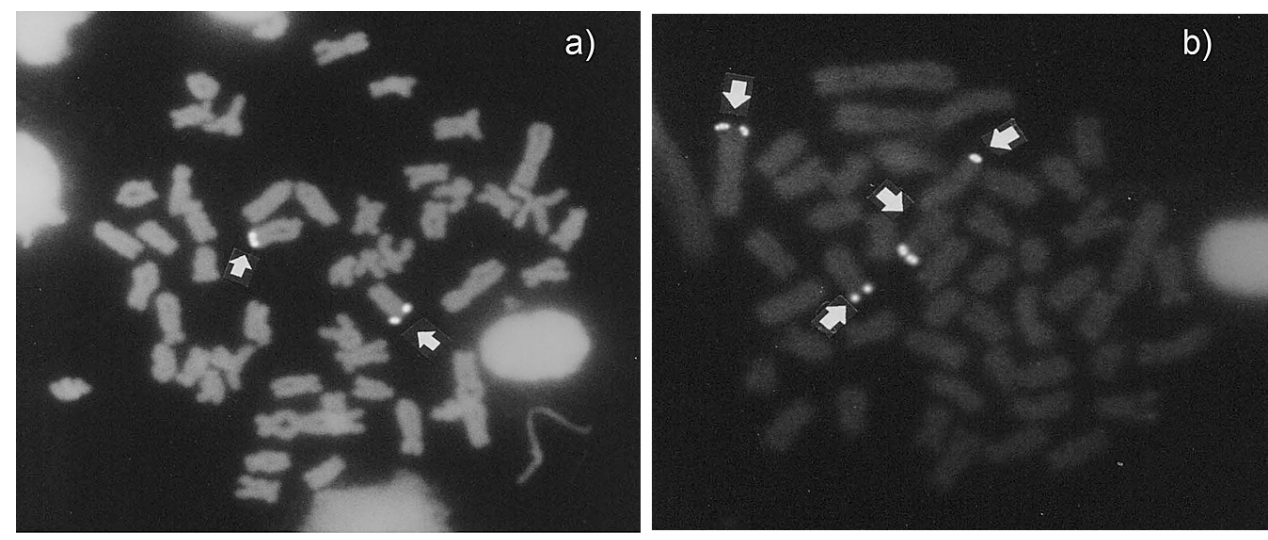

Fig. 4. Somatic metaphases of Astyanax scabripinnis from (a) Machado river hardwater and (b) Pedra Branca stream after $\mathrm{CMA}_{3}$ staining. The arrows shows $\mathrm{GC}$ rich regions.

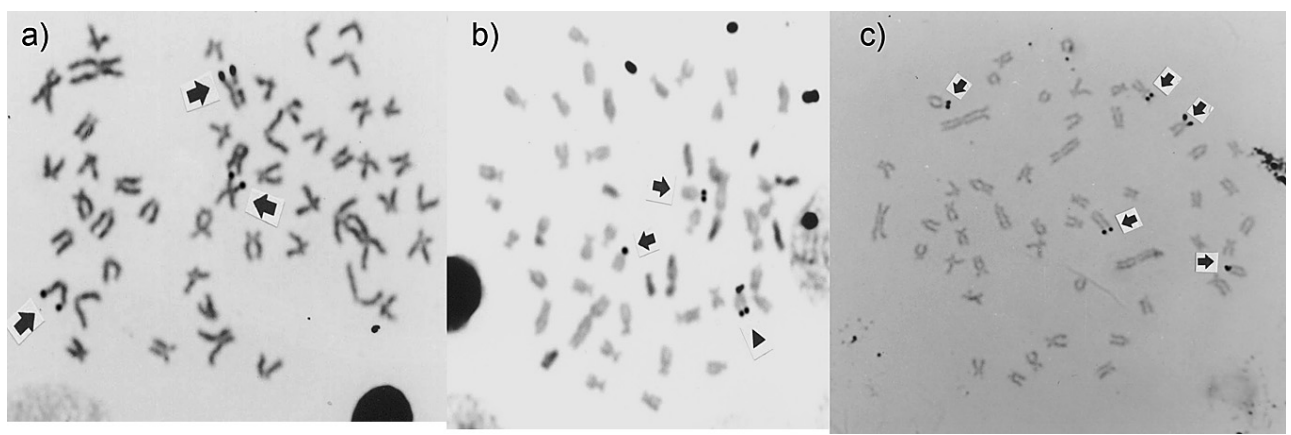

Fig. 5. Somatic metaphases of Astyanax scabripinnis showing Ag-NOR-bearing chromosomes (arrows): a) sample from Cambeba stream, b) sample from Machado river hardwater (arrowhead shows bitelomeric NOR), and c) sample from Pedra Branca stream. 
2004).

The $\mathrm{CMA}_{3}$ staining, a GC specific fluorochrome, was performed only on Machado river and Pedra Branca stream and showed bright signals on 2 different chromosomes in Machado river samples and on 4 chromosomes in Pedra Branca samples, and the signals were coincident with some NOR-bearing chromosomes stained with silver nitrate (Fig. 4a,b). The silver nitrate staining showed multiple NORs, with a modal number of 2 marks, on 3 A. scabripinnis populations studied in this study (Fig. 5a, b, c). Populations from Cambeba stream and Machado river hardwater showed the maximum number of 3 chromosomes bearing Ag-NOR, with the observation of one bitelomeric NOR in 1 sample from Machado river, and population from Pedra Branca stream showed until 5 chromosomes bearing these sites. A. scabripinnis from Cambeba stream was the unique that not presented Ag-NORs in the short arm of 1 ST-A chromosome pair. This common NOR-bearing chromosome (ST) has been identified as the NOR-bearing one in several local populations of $A$. scabripinnis (Souza and Moreira-Filho 1995, Maistro et al. 1998, Maistro et al. 2000). Differences in number and/or NOR position in A. scabripinnis were also reported by several authors (MoreiraFilho 1989, Maistro et al. 1998, Rocon-Stange and Almeida-Toledo 1993).

Despite the occurrence of extensive diversification in karyotype morphology among the Astyanax scabripinnis populations, the majority has unchanged diploid numbers. In these cases, rearrangements that modify the centromere position such as pericentric inversions appear to be predominant in chromosome diversifications. For instance, those populations which show chromosome number $2 n=48$ and $2 n=46$ may represent derived evolutionary states and the main rearrangement responsible for the reduction in diploid number appears to have been the centric fusions. The frequency of chromosomal rearrangements (including heterochromatin additions) varies considerably as a function of many interrelated internal (e.g., molecular, cytomechanical, meiotic) and external factors (e.g., effective populations size, gene flow) (Spirito 1992, Sites-Jr. and Reed 1994). The fact that A. scabripinnis occur exclusively in the head waters of small streams and represent isolated reproductive populations favors the notion of chromosome rearrangements and fits the model of population evolution proposed by Wilson et al. (1975).

\section{Acknowledgments}

The authors are grateful to Dr. Francisco Langeani Neto for the taxonomic identification of the species and to Lucimara Maria da Silva for his technical assistance.

\section{References}

Bertollo, L. A. C., Takahashi, C. S. and Moreira-Filho, O. 1978. Cytotaxonomy considerations on Hoplias lacerda (Pisces, Erithrinidae). Rev. Bras. Genet. 1: 103-120.

Caramaschi, E. P. 1986. Distribuição da ictiofauna de riachos das bacias do Tietê e do Paranapanema, junto ao divisor de água (Botucatu, SP). Doctoral Thesis, Universidade Fedral de São Carlos, Brazil.

Eigenmann, C. H. 1921. The American Characidae. Mem. Mus. Comp. Zool. 23: 209-310. Cambridge.

Foresti, F., Oliveira C. and Almeida-Toledo, L. F. 1993. A method for chromosome preparations from large fish specimens using in vitro short-term treatment with colchicine. Experientia 49: 810-813.

Fowler, H. W. 1948. Os peixes de água doce do Brasil. Arquivos de Zoologia. 6: 1-204. Departamento de Zoologia da Secretaria da Agricultura do Estado de São Paulo, Brazil.

Gomes, A. L. and Azevedo, P. 1960. Os peixes de Monte Alegre do Sul, Estado de São Paulo. Papéis Avulsos, Departamento de Zoologia, SP. 14: 133-151.

Howell, W. M. and Black, D. A. 1980. Controlled silver-staining of nucleolus organizer regions with a protective colloidal developer: a 1-step method. Experientia 36: 1014-1015.

Levan, A., Fredga, K. and Sandberg, A. A. 1964. Nomenclature for centromeric position on chromosomes. Hereditas 52: 201-220.

Maistro, E. L., Foresti, F. and Oliveira, C. 1998. Comparative cytogenetic and morphological analysis of Astyanax scabrip- 
innis paranae (Pisces, Characidae, Tetragonopterinae). Genet. Mol. Biol. 21: 201-206.

-, Oliveira, C. and Foresti, F. 2000. Sympatric occurrence of two cytotypes of Astyanax scabripinnis (Characiformes, Characidae). Genet. Mol. Biol. 23: 365-369.

- - - and - 2001. Cytogenetic characterization of a supernumerary chromosome segment ando f B-chromosomes in Astyanax scabripinnis (Teleostei, Characidae). Genetica 110: 177-183.

Mantovani, M., Abel, L. D. S., Mestriner, C. A. and Moreira-Filho, O. 2004. Evidence of the differentiated structural arrangement of constitutive heterochromatin between two populations of Astyanax scabripinnis (Pisces, Characidae). Genet. Mol. Biol. 27: 536-542.

Melo, F. A. G. 2001. Revisão taxonômica das espécies do gênero Astyanax Barid e Girard, 1854 (Teleostei: Characiformes: Characidae) da região da Serra dos Órgãos. Arq. Mus. Nac. 59: 1-46. Rio de Janeiro.

Mizoguchi, S. M. H. M. and Martins-Santos, I. C. 1998. Cytogenetic and morphometric differences in populations of Astyanax "scabripinnis" (Pisces, Characidae) from Maringá regions, PR, Brazil. Genet. Mol. Biol. 21: 55-61.

Moreira-Filho, O. 1989. Análises cariotípicas e morfológicas sobre a diversidade no "complexo" Astyanax scabripinnis (Jenyns, 1842) (Pisces, Characidae, Tetragonopterinae). Doctoral thesis. Univ. Federal de São Carlos, São Carlos, SP, Brasil.

— and Bertollo, L. A. C. 1991. Astyanax scabripinnis (Pisces, Characidae): a species complex. Braz. J. Genet. 14: 331-357.

Rocon-Stange, E. A. R. and Almeida-Toledo, L. F. 1993. Supernumerary B-chromosomes restricted to males in Astyanax scabripinnis (Pisces, Characiformes). Braz. J. Genet. 16: 601-615.

Schweizer, D., 1980. Simultaneous fluorescent staining of R bands and specific heterochromatic regions (DA-DAPI bands) in human chromosomes. Cytogen. Cell Genet. 27: 190-193.

Sites-Jr., J. W. and Reed, K. M. 1994. Chromosomal evolution, speciation, and systematics: some relevant issues. Herpetologica 50: 237-249.

Souza, I. L., Moreira-Filho, O. and Bertollo, L. A. C. 1995. Cytogenetic diversity in the Astyanax scabripinnis (Pisces, Characidae) complex. II. Different cytotypes living in sympatry. Cytologia 60: 273-281.

Spirito, F. 1992. The exact values of the probability of fixation of underdominant chromosomal rearrangements. Theor. Pop. Biol. 41: 111-120.

Sumner, A. T. 1972. A simple technique for demonstrating centromeric heterocromatin. Exptl. Cell Res. 75: 304-306.

Wilson, A. C., Bush, G. L., Case, S. M. and King, C. 1975. Social structuring of mammalian populations and rate of chromosomal evolution. Proc. Nat. Acad. Sci. USA 72: 5061-5065. 